\title{
Situation in the Polish housing market compared to other EU countries
}

\author{
Marcin Sitek \\ Częstochowa University of Technology \\ Poland \\ sitek_m@poczta.onet.pl
}

\begin{abstract}
The aim of this study is to analyse situation in the Polish housing market in 2009-
Received:

June, 2014

2013 against the background of other EU countries. This article describes a deficit situation in the housing market, housing resources, the number of flats built per year and governmental programmes to support housing. The study examines the problems of flats for rent by comparing their percentage in Poland with the percentage of flats in the European Union. The situation in the Polish housing market was analysed from the standpoint of the vision of social market economy for Europe of the $21^{\text {st }}$ century.

1st Revision: September, 2014

Accepted:

October, 2014

DOI:

$10.14254 / 2071-$ $8330.2014 / 7-2 / 5$
\end{abstract}

Keywords: housing market, deficit of flats, floor space, flats for rent.

JEL Classification: O19, P35, R31

\section{INTRODUCTION}

The role of real estate as a component of national wealth, its market character, and specific characteristics as a commodity or an object of investment causes it takes one of the main places in any market economy.

A high level of capital intensity means that especially in commercial and industrial real estate are particularly dominated by institutional investors, such as financial institutions-companies that invest in real estate and banks.

Although financial outlays for investments in commercial and industrial real estate are usually the highest in the sector, high capital intensity is also observed for other types of real estate, which often forces financing from foreign sources. One external source of financing in the real estate market is banks. The banking sector's involvement in financing the real estate market also from the willingness to reduce market risk, a positive effect of financial leverage and creation of real estate portfolios.

Until the period of transformation in 1989, specific housing real estate resources had been considered assets with a social aspect that were used to meet housing needs.

The transformation of Poland's system towards a market economy (early 1990s) started the perception of real estate as an object of investment.

Poland started the period of transformation with a relatively low level of housing: in 1991, some 3.6 new housing units (a house or a flat) were built per 1,000 inhabitants. The main suppliers of flats were housing cooperatives which built over 83,000 flats. The majority of flats in multi-family construction were built using large-panel technologies. 
The data published by the Central Statistical Office (2013) in Poland, Reas (2014), Kongres Budownictwa (2009) and Bank BGŻ (2014) were used for analysis of changes in dynamics of housing construction sector in the period of 1993-2013.

The dynamic of changes in housing real estate expressed as a number of housing units built in Poland in 1993 to 2013 is presented in Diagram 1. The number of flats built was decreasing in individual years, reaching its minimum (slightly below 62,000) in 1996 (Kongres Budownictwa, 2009). Since this moment, a slow increase started, reaching the level of 115,000 in 2005.

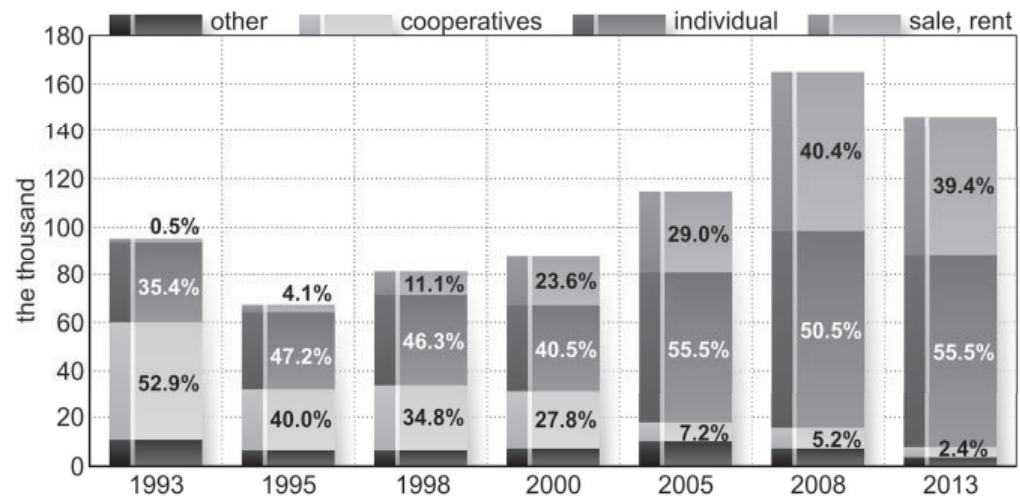

Diagram 1. Structure of housing units built in Poland in 1993-2013 depending on the category of investor (category "other": social housing associations, communal flats, company's flats)

Source: Bank BGŻ (2014)

According to Kirejczyk (Kongres Budownictwa, 2009) substantial anomalies were observed in 2003, concerning the high number of housing units built (over 162,000). This number probably results from the inclusion of ca. 70,000 to 80,000 detached houses which were claimed in previous years but actually had not been built and settled.

If analysis is restricted only to the flats according to a category specified by the Central Statistical Office as "for rent or sale", the dynamics of changes in the structure of flats built in 1993-2013 points to an increase in the level of developer's building investments (flats for sale or rent and ca. 10\% of individual building sector for investment purposes). The data point to progressing marginalization of building activity of cooperatives: gradual decline in the number of flats built by cooperatives: $52.9 \%$ of overall number of flats built in 1993 compared to $2.4 \%$ in 2013). In the eighties of the 20th century, the cooperatives built 160,000 flats per year, whereas in 2013, this number was 3,500 flats.

According to the statistical data and estimates of the Central Statistical Office (2013), the number of households in Poland at the end of 2011 amounted to ca. 14.65 million. The total number of housing units built in Poland in 2011 including individual building for investment purposes was ca. 13.59 million. The flats-to-household ratio was merely 0.93 . This result was similar to that of 2002 . This means that within 10 years (2002-2011), a deficiency of flats was established and, in order to stop this unfavourable trend, it would be necessary to significantly increase the number of flats built. Poland is one of the last countries in Europe to have lower number of flats compared to households. 
This study uses the data from the Baza Rynku Nieruchomości (BaRN - Real Estate Market Database), Ogólnopolskie Raporty o Kredytach Mieszkaniowych i Cenach Transakcyjnych Nieruchomości AMRONSARFIN (National Reports on Housing Credits and Real Estate Transactional Prices), Związek Banków Polskich (Polish Banks Association); the analyses and reports by the Komisja Nadzoru Finansowego (KNF Polish Financial Supervision Authority); and collective data published by Biuro Informacji Kredytowej (BIK - Credit Information Bureau). This study also analyses the data published by the Central Statistical Office (GUS) and the number of studies containing the data concerning the sector studied.

The data were used for analysis of quantitative and property-based structure of flats built in 2013 . This structure was compared with the structure of flats built in the countries of the European Union.

The structures and dynamics of changes were analysed using the comparative method.

\section{SITUATION OF THE POLISH REAL ESTATE MARKET IN THE POST-CRISIS PERIOD COMPARED TO THE EUROPEAN UNION COUNTRIES}

In the beginning of 2009, banks started to implement more restricted policies for mortgages. They ended the practice of lending the equivalent of $100 \%$ of the real estate value and became less willing to grant mortgages, or even ceased to grant them. Regular increases in interest rates by the Monetary Policy Council were followed by a rise in the cost of mortgages. Between March 2007 and December 2008, the interest rate for mortgages increased from $5.6 \%$ to ca. $8 \%$; between January and November 2009, it fell from $8.24 \%$ to 6.79\% (KNF, 2006, 2007, 2008).

The interest rate for Swiss franc-denominated mortgages has also increased. In the period of November 2007 to January 2009 the interest rate increased from 4.14\% to 4.55\%; in November 2009, it was 4.05\% (KNF, 2010). It was expected that the mortgage portfolio in December 2008 would be 109 billion zlotys, the level of Polish-zloty mortgages would be 46.7 billion zlotys, and mortgages in foreign currencies 62 billion zlotys, with a mean spread for mortgages in Polish zlotys (PLN) of $1.2 \%$. These prognoses were accurate for two/three quarters of 2008 . However, when the crisis started, the mean spread in 2008 rose substantially to $1.72 \%$, and the number of mortgages granted declined substantially.

The global situation and revival in the mortgage market has been seen since 2009. The recession stabilized: in November 2009, for the first time in seven months, a decline in the average level of spread for Polish zloty mortgages was observed. (The interest rate on a mortgage includes a spread expressed in percentage terms, which is constant throughout the contract period, and the market rate such as WIBOR.) Furthermore, the spread offered by banks is lower in promotion campaigns for customers who buy additional banking products. There are also a number of options offered by banks to reduce or even forgo mortgage banking fees. Additionally, banks have liberalized their approach concerning the required contribution by customers.

The revival in the mortgage market was also manifested by an increase in credit standing, i.e. the maximum amount of money which a bank is willing to grant as a loan to a borrower who meets particular conditions.

All these activities point to a substantial revival in the market for mortgages and consistent improvement in the mortgage situation. In the late autumn of 2009, the post-crisis situation was gradually improving. This contributed to new lending (although in limited scope) by banks, the implementation of an insignificant number of corrections which were advantageous to customers and support granted to buyers by governmental program "Rodzina na Swoim" ("Family with Its Own Flat") (the programme partially overtook the role of currency-denominated loans in financing the purchase of real estate). Loan spreads continued to decline but interest rates were relatively steady. Since demand is still dominant in the market, 
a dynamic increase in the prices of flats was observed in 2010. The sale of flats will, however, increase, especially due to changes in housing preferences among Poles forced by the economic situation (most flats sold in Poland are lower-price). This increase was connected with the limited supply of the most popular types of flats. This increase accounted for $7 \%$ of the whole market. Furthermore, banks reported an increase in the number of mortgages granted by ca. $10 \%$ to $15 \%$ per year.

From 2010, cheaper and more accessible mortgages were available. Banks extended their promotion campaigns, often withdrew their fees, reduced spreads and were more willing to finance a greater part of real estate than before. It is worth noting a revival in the terms of mortgages, even despite implementation of the Recommendation $T^{1}$ prepared by the Polish Financial Supervision Authority in order to enforce standards for requirements of credit standing of individual customers. The second half of 2010 brought substantially more attractive services and products offered by banks. They concerned both reductions in spreads and continued liberalization of the conditions of granting mortgages.

Diagram 2 shows the housing construction sector in Poland in 2009 to 2013, expressed as a number of flats with construction permissions granted in the most recent 12 months, the number of flats with construction started in the most recent 12 months, and a curve that characterizes the supply of flats in the period studied.

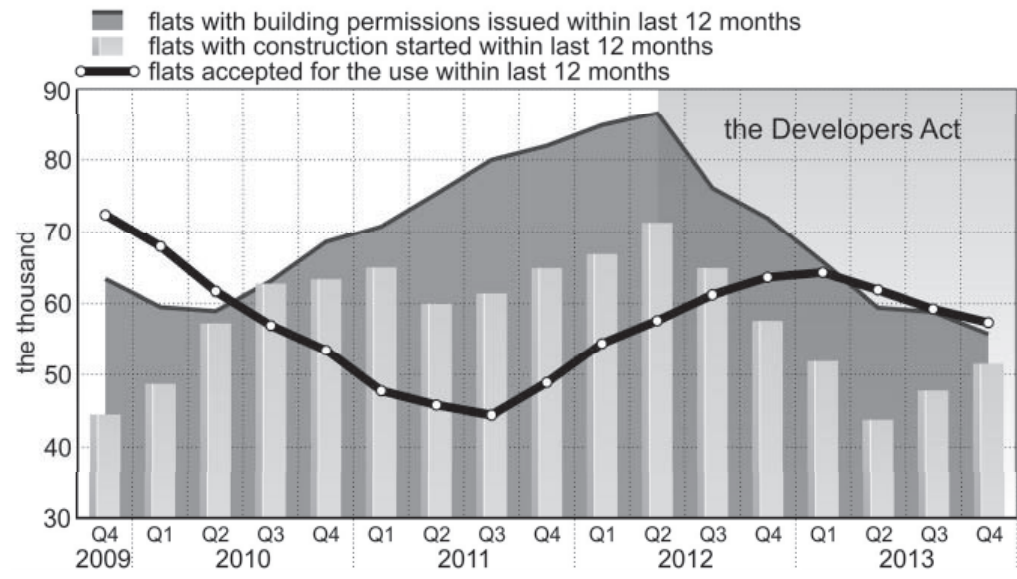

Diagram 2. Housing construction sector in Poland

(developers' flats, the category by the Central Statistical Office: for sales or rent)

Source: Bank BGŻ (2014)

Diagram 2 shows that the supply of flats, particularly in 2013, was determined by the implementation of the Developers Act at the end of April 2012 (The Act of September, 2011). The new act is expected to prevent from malpractices connected with concluding and realization of developer's contracts and protect the rights of purchasers in case of developer's bankruptcy. With respect to the investments implemented

\footnotetext{
1 Recommendation $T$ restricted quantitative criteria for calculation of credit standing of a customer with respect to the incomes they obtain and costs of living and financial obligations they have to repay. It implements a standard of verification of customers in the Credit Information Bureau. Total of monthly instalments from credits and loans cannot be higher than the half of household income.
} 
with so-called developer's system, i.e. from the resources paid by the customers, the money paid will not become the current assets of the developer but they will be redirected to one of the three types of escrow accounts. Escrow account is obligatory.

The resources from the escrow account will be paid to the developer after completion of the investment (in the case of closed escrow account) or after completion of a stage of the investment (in the case of open escrow account or open escrow account with insurance or banking guarantee). In this case, the payment of the part of resources occurs after completion of a specific stage in advancement of construction works (adequately to its level) after controlling it by the bank.

Furthermore, in the event of developer's bankruptcy, only the people that concluded the preliminary agreement in the form of the notarial deed will be best protected since presence of the solicitor improves the safety of transactions, but preparation of the preliminary agreement in the form of the notarial deed means additional costs for purchasers.

This resulted in an intensification of construction works in the beginning of 2012, and then a slowdown in the number of new building sites in the following months. The high number of offers in the market that followed this situation was maintained until 2013; whereas developers, especially in the first half of 2013, were not willing to start new investments. Therefore, the number of flats under the category "for sale and rent" which were granted construction permissions in 2013 declined by $22.4 \%$ YoY, and the number new building sites started decreased by $10.6 \%$ YoY (a decline in this category in the first half of 2013 was even more substantial, 39.5\% YoY).

A decline in supply was also confirmed by REAS (2014) statistics, which demonstrated that new offers of sales in 2013 in the six biggest cities in Poland represented over 24,000 flats and was significantly lower compared to the mean from recent several years, equal to 35,000 to 37,000 new flats. Moreover, most of the flats offered for sale in 2013 were still not subject to the requirement of ensuring an escrow account to the purchasers (in the third quarter of 2013, banks had 300 such accounts, i.e. $12 \%$ of all investments). As presented in Diagram 2, the number of flats built substantially decreases in the post-crisis period (the lowest level occurs in the third quarter 2011). Furthermore, the number of flats that were started to be built in the period from the third quarter of 2011 substantially rose until the first quarter of 2013, and then slowed down.

According to Eurostat, comparison of the number of rooms to the number of adults and children living in households represents a criterion for overcrowding. According to the EU Statistical Office (PZFD, 2012), the problem of overcrowded flats concerned $18 \%$ of the inhabitants of the EU and as many as $49 \%$ of the citizens of Poland. This difficult situation in the Polish housing market was caused by both overpopulation and low purchasing power in the population.

The average monthly salary in Poland is sufficient for buying ca. $0.8 \mathrm{~m}^{2}$ of a flat's surface area. An even worse situation is observed in the biggest cities, where the average salary is sufficient for buying of ca. 0.5 to $0.6 \mathrm{~m}^{2}$ of a flat (Council of Ministers, 2011). In Western European countries, the average salary allows for buying ca. 2 to $3 \mathrm{~m}^{2}$ of a flat. In Poland, the purchase of an average-size flat requires spending 6- to 8-year salaries, whereas in better developed countries, this can be satisfied with 2.5- to 3.5-year salaries (NBP, Biuro Polityki Makrostabilnościowej, 2014; Łaszek, 2004).

Low incomes and high costs of construction or prices of new flats means that only part of society can meet its housing needs directly in the market. It seems that the only factor that substantially improves financial capacity of households with average incomes in the housing sector is long-term financing that adopts the form of a mortgage. Availability of loans, especially mortgage loans, has in recent years increased substantially through competition and progressing economic stabilization, but it is still lower than in highlydeveloped countries. 
Driven by limitation of the supply with the increase in demand in the primary real estate market, the period necessary to sell the whole offer of flats reduced in 2013 (from ca. 1.5 to 4.4 quarter). The shortest time necessary to sell all the offer of flats from the primary market, which accounts for 4.2 quarter was reported in Warsaw, whereas the longest one was found for Łódź (5.4 quarter) (Bank BGŻ, 2014). Furthermore, with respect to the excess number of the building permissions granted, it can be concluded that the developers are able to improve the statistics of supply soon.

The structure of the supply offer according to the date of completion of the project in 6 months declared by developers (status as of 2013) was presented in Fig. 1.

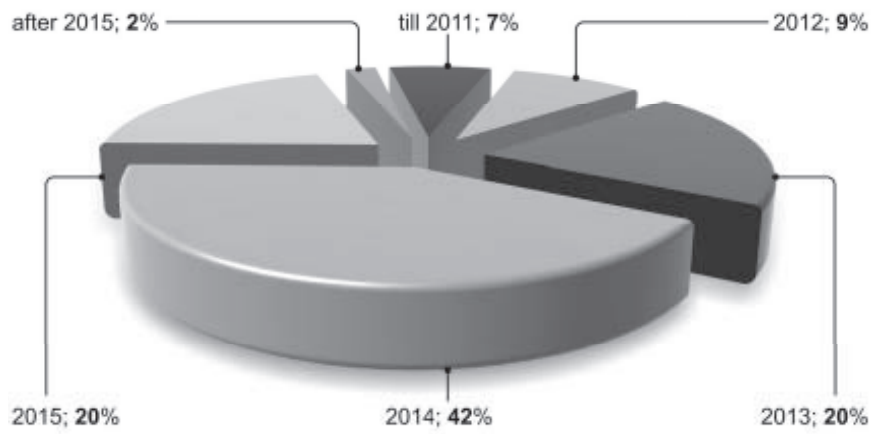

Figure 1. Structure of offer according to the date of completion of the project declared by the developer (Warsaw, Kraków, Tricity, Wrocław, Poznań, Łódź, status as of the end of 2013)

Source: Bank BGŻ (2014)

The data presented in Fig. 1 show that the decline in current offers, with low share of building sites already started with deadline of completion after 2015, must contribute to starting new housing investments. If improvement in the economic status of the country is continued and the demand does not fade away, it should be expected that the increase in new investments year over year should be positive.

Improvement in the economy, with particular focus on very low interest rates with relatively low prices of flats generated in 2013, show a strong demand impulse. The number of residential flats sold by certain leading developers is presented in Table 1.

Table 1

Number of flats sold by selected market leaders among developers

\begin{tabular}{|c|c|c|c|c|c|c|c|c|c|c|}
\hline \multirow{2}{*}{ Developer } & \multirow{2}{*}{2008} & \multirow{2}{*}{2009} & \multirow{2}{*}{2010} & \multirow{2}{*}{2011} & \multirow{2}{*}{2012} & \multirow{2}{*}{2013} & \multicolumn{4}{|c|}{2013} \\
\hline & & & & & & & I & II & III & IV \\
\hline Robyg & No data & No data & No data & 1015 & 1264 & 1731 & 303 & 402 & 476 & 550 \\
\hline $\begin{array}{l}\text { Gant } \\
\text { Development }\end{array}$ & 752 & 541 & 929 & 857 & 771 & No data & $75^{*}$ & No data & No data & No data \\
\hline $\begin{array}{l}\text { JW.Construc } \\
\text { tion* }\end{array}$ & 530 & 827 & 1262 & 1016 & 852 & 941 & 189 & 205 & 275 & 272 \\
\hline $\begin{array}{l}\text { Dom Develop- } \\
\text { ment }\end{array}$ & 994 & 712 & 1375 & 1716 & 1451 & 1605 & 339 & 386 & 414 & 466 \\
\hline
\end{tabular}




\begin{tabular}{|l|c|c|c|c|c|c|c|c|c|c|}
\hline Polnord & $1046 * *$ & 441 & 764 & 1086 & 943 & 1096 & 200 & 212 & 283 & 401 \\
\hline Ronson Europe & $88^{* * *}$ & 265 & 269 & 358 & 472 & 572 & 132 & 163 & 123 & 154 \\
\hline $\begin{array}{l}\text { Budimex } \\
\text { Nieruchomości }\end{array}$ & No data & No data & No data & 753 & 562 & 742 & 121 & 159 & 214 & 248 \\
\hline Marvipol & $173 * * *$ & 247 & 218 & 509 & 417 & 588 & 121 & 103 & 203 & 161 \\
\hline Inpro & No data & No data & No data & 426 & 366 & 416 & 62 & 90 & 106 & 158 \\
\hline
\end{tabular}

* gross (without withdrawals), ${ }^{* *}$ Polnord informed about selling 717 flats, including the project in Gdańsk (a land with building permission, almost 630 flats) sold with profits to other enterprises.

*** lack of the results of sales in the 3 rd quarter

Source: ZBP (2013), PZFD (2012), Bank BGŻ (2014)

The demand that grew quarter over quarter and accounted for 10.9 flats (according to REAS) in the last quarter of 2013 was comparable with sales in the boom peak, i.e. in the beginning of 2007. In 2013, sales were at the level of 36,000 flats, i.e. an increase of 17.5\% YoY, and similar to record figures in 2007. These very good results of sales are confirmed by stock exchange developers, who demonstrated increases that have not been recorded since the boom; according to NBP, ca. $70 \%$ of total sales of flats was covered by large entities.

According to a report by PZFD (2012), with respect to flats that were in a bad technical condition necessitating replacement with a new resource (ca. 3\% of the housing resource whose renovation is unprofitable), some 1.5 million flats might be needed in Poland, although governmental estimates ${ }^{2}$ in 2011 showed a deficit of even 2 million flats.

Prognosis of the housing deficit in Poland in 2012 - 2022 (Forsal, 2011):

\section{DEFICIT}

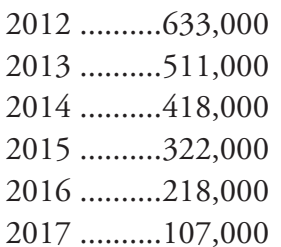

\section{SURPLUS}

2018 ...........7,000

2019 ...........129,000

2020 ...........254,000

2021 ............380,000

2022 ..........508,000

Estimation of the number of flats per 1,000 inhabitants in Poland shows that there are 351.1 flats in Poland per 1,000 inhabitants, which represents the lowest number of flats in Europe. The number of flats per 1,000 inhabitants in Europe is presented in Diagram 3.

Furthermore, according to the data of the EU Statistical Office (PZDF, 2012), one room per person is recorded in Poland, which puts Poland at the penultimate place in Europe, followed only by Romania. Since Poland's accession to the European Union, the situation in these terms remains unchanged. In Lithuania, Latvia, Estonia or the Czech Republic, the index defining the number of rooms per person in recent years has been substantially improved, demonstrated by the data presented in Table 2.

2 The data contained in the "Projekt założeń projektu ustawy o zmianie ustawy o niektórych formach popierania budownictwa mieszkaniowego" ("Project of assumptions for the act on amending the act on some forms of supporting housing building") as of August 31, 2011. 


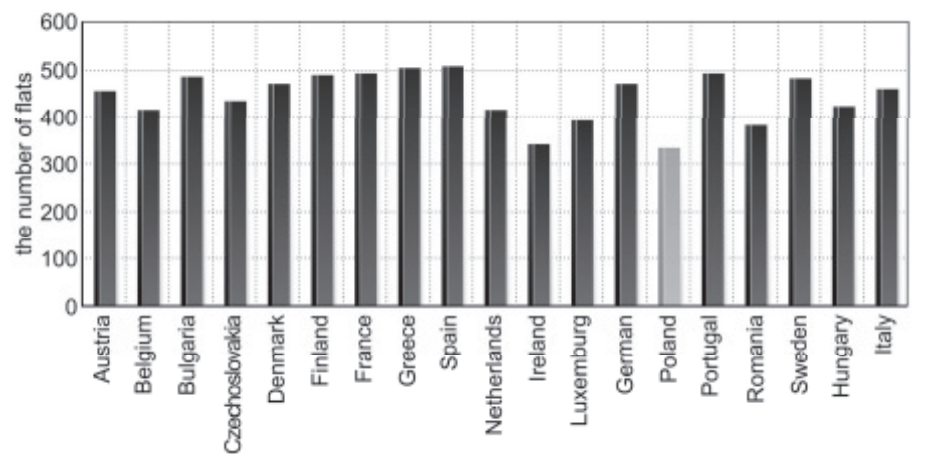

Diagram 3. The number of flats per 1,000 inhabitants in Europe (status as of 2011) Source: Instytut Analiz-MRN (2011).

The survey concerning housing conditions in Polish households carried out by the Department of Social Surveys and Living Conditions of the Central Statistical Office in Poland demonstrated that some 20\% of the respondents find their flats too small and $15.4 \%$ of them live in the flats with leaking roofs; dank walls, floors, or foundations; or rotten windows or floors.

The lowest costs of utilization in Poland for the year 2010 calculated per 1 square metre of functional surface were found for flats in housing communities (32.6 zlotys), whereas the highest costs were recorded for the assets of the State Treasury (96.0 zlotys) (GUS, 2010). These data support the thesis that the highest cost efficiency can be observed for flats which are owned by private persons, whereas the flats from public resources are the most expensive and the most poorly managed. The flats from communal resources are also very quickly degraded in technological terms due to the lack of care for flats obtained from the state and poor supervision of these flats.

The above data show that extension of communal resources is uneconomical, whereas the system of communal flats should be replaced by a system for supporting the ability of people with the lowest incomes to rent a flat in the free market. This suggestion seems to guarantee prevention of overcrowding, with the overcrowding index for Poland decreasing steadily since 2004. However, it should be noted that this occurred with a reduction in the surface area of rooms added to the market and, since 2010, the number of multi-room flats introduced in the market has been significantly reduced.

Reduction in the surface area of flats being built is caused by the reduced purchasing power in the population, itself caused by restricted conditions of granting mortgages and the ratio of prices of flats to incomes in the population.

According to Eurostat (GUS 2010) in 2010 81.5\% of the inhabitants of Poland lived in houses and flats that they owned. The mean in the EU was $70.7 \%$ and, for the countries of the "old EU", this percentage was only $66.9 \%$. The highest percentage of flats rented in the overall number of flats in the EU is observed in Austria, with an index of $42.3 \%$. The data for Germany are estimated at $44 \%$. The lowest percentage of flats rented in overall number of flats in the EU was recorded in Romania, at 3.5\%. 
Table 2

Number of rooms per person (selected countries in 2004-2010)

\begin{tabular}{|c|c|c|c|c|c|c|c|}
\hline GEO/TIME & 2004 & 2005 & 2006 & 2007 & 2008 & 2009 & 2010 \\
\hline European Union (27 countries) & & 1.5 & 1.5 & 1.6 & 1.6 & 1.6 & 1.6 \\
\hline European Union (15 countries) & & 1.7 & 1.7 & 1.7 & 1.7 & 1.7 & 1.7 \\
\hline $\begin{array}{l}\text { New Member States } \\
(12 \text { contries })\end{array}$ & & & & 1.0 & 1.0 & 1.1 & 1.1 \\
\hline Belgium & 2.1 & 2.2 & 2.2 & 2.2 & 2.2 & 2.3 & 2.1 \\
\hline Bulgaria & & 1.0 & 1.0 & 1.0 & 1.0 & 1.0 & 1.1 \\
\hline Czech Republic & & 1.2 & 1.2 & 1.2 & 1.2 & 1.3 & 1.4 \\
\hline Denmark & 1.9 & 1.9 & 1.9 & 1.9 & 1.9 & 1.9 & 1.9 \\
\hline $\begin{array}{l}\text { Germany (including former GDR from } \\
\text { 1991) }\end{array}$ & & 1.7 & 1.7 & 1.7 & 1.7 & 1.7 & 1.8 \\
\hline Estonia & 1.1 & 1.1 & 1.1 & 1.2 & 1.2 & 1.2 & 1.2 \\
\hline Ireland & 2.0 & 2.0 & 2.0 & 2.0 & 2.0 & 2.1 & 2.1 \\
\hline Greece & 1.2 & 1.2 & 1.2 & 1.2 & 1.2 & 1.2 & 1.2 \\
\hline Spain & 1.5 & 1.7 & 1.8 & 1.9 & 1.9 & 1.9 & 1.9 \\
\hline France & 1.7 & 1.7 & 1.7 & 1.7 & 1.7 & 1.8 & 1.8 \\
\hline Italy & 1.4 & 1.4 & 1.4 & 1.4 & 1.4 & 1.4 & 1.4 \\
\hline Cyprus & & 1.8 & 1.9 & 1.9 & 1.9 & 2.0 & 2.0 \\
\hline Latvia & & 0.9 & 0.9 & 0.9 & 1.0 & 1.0 & 1.0 \\
\hline Lithuania & & 1.0 & 1.0 & 1.0 & 1.0 & 1.1 & 1.1 \\
\hline Luxembourg & 1.8 & 1.8 & 1.8 & 1.8 & 1.8 & 1.9 & 1.9 \\
\hline Hungary & & 1.0 & 1.0 & 1.0 & 1.0 & 1.1 & 1.0 \\
\hline Malta & & 2.0 & 2.0 & 2.0 & 2.0 & 2.0 & 2.0 \\
\hline Netherlands & & 2.0 & 2.0 & 2.0 & 2.0 & 2.0 & 2.0 \\
\hline Austria & 1.6 & 1.6 & 1.6 & 1.6 & 1.6 & 1.7 & 1.7 \\
\hline POLAND & & 1.0 & 1.0 & 1.0 & 1.0 & 1.0 & 1.0 \\
\hline Portugal & 1.4 & 1.4 & 1.4 & 1.4 & 1.4 & 1.5 & 1.4 \\
\hline Romania & & & & 0.9 & 0.9 & 0.9 & 0.9 \\
\hline Slovenia & & 1.1 & 1.1 & 1.1 & 1.1 & 1.1 & 1.1 \\
\hline Slovakia & & 1.0 & 1.0 & 1.1 & 1.1 & 1.1 & 1.1 \\
\hline Finland & 1.8 & 1.8 & 1.8 & 1.9 & 1.9 & 1.9 & 1.9 \\
\hline Sweden & 1.7 & 1.7 & 1.8 & 1.7 & 1.7 & 1.8 & 1.7 \\
\hline United Kingdom & & 1.8 & 1.8 & 1.8 & 1.8 & 1.8 & 1.8 \\
\hline Iceland & 1.6 & 1.6 & 1.6 & 1.6 & 1.6 & 1.6 & 1.6 \\
\hline Norway & 1.9 & 1.9 & 2.0 & 2.0 & 2.0 & 2.0 & 2.0 \\
\hline Switzerland & & & & & 1.7 & 1.7 & 1.8 \\
\hline
\end{tabular}

Source: PZDF (2012).

The mean share of expenditures in two-person households per flat rental costs in Poland, expressed as a ratio of expenditures per flat rent to overall total of expenditures of two-person households, amounts to $30 \%$ of expenditures, putting Poland at the penultimate place in the EU.

- In Poland: $37.5 \%$ of the population that rent flats spend $40 \%$ of overall expenditures for rent. 
- In Austria: only 10.6\% of the population that rent flats spend more than $40 \%$ of overall expenditures for rent.

- In Romania: 67\% of the population that rent flats spend $40 \%$ of overall expenditures for rent.

The mean European costs of flat rent amounts to $26.5 \%$.

In 2011, the barriers for construction activity resulting from the lack of certainty with respect to economic stability became rapidly more serious. It is necessary to take actions to increase opportunities for investment in housing real estate through improvement of the regulations concerning the market of flat rent.

\section{SUPPORT FOR MEETING THE HOUSING NEEDS WITH RESPECT TO SOCIAL VISION OF THE MARKET ECONOMY FOR EUROPE OF THE 21ST CENTURY}

Since 2014, the substantial drivers for the real estate market have been from governmental projects (Regiodom, 2014): Fundusz Mieszkań na Wynajem (Flats-for-Rent Fund) and the programme of subsidies to mortgages Mieszkanie dla Młodych (Flats for Young People). Bank Gospodarstwa Krajowego (BGK) established an entity named BGK Nieruchomości to manage a fund which is expected to launch in the first quarter of 2014. According to the announcement of the BGK, the first flats for rent will be available in the fund in 2014 or 2015.

According to the assumptions, the flats-for-rent fund is expected to buy new and equipped flats in the agglomeration where the needs for rent are the greatest. The focus will be on Warsaw, Kraków, Wrocław, Tricity (Gdańsk, Gdynia and Sopot), Poznań and Łódź. According to Kuszewski (Gazeta Bankowa, 2014), director of the Department of Capital Investments in the Bank Gospodarstwa Krajowego, prospective tenants will pay rent less than the market price by ca. $20 \%$. The fund is supposed to operate on market basis. The fund is not intended to buy individual flats but whole buildings. The buildings are expected to include flats up to 60 square metres, including bedsitters, built using technologies adjusted for the needs of the rent market.

In the coming years, BGK plans to invest 5 billion zlotys through the fund. This will allow for building a portfolio of up to 20,000 flats in the biggest cities. On the one hand, the activity of the fund should increase competition in the rental market and lead to a reduction in rent rates. On the other hand, the prices of flats can be increased in the popular segments of the biggest cities (where the fund is intended to operate).

According to the data presented by Eurostat, in Poland only $4 \%$ of households live in a flat rented under market conditions. A similar situation is observed in other countries of the "new EU". This percentage in the Netherlands, Denmark and Germany ranges from 30 to $40 \%$ and accounts for over $50 \%$ in Switzerland. The programme Fundusz Mieszkań na Wynajem (Flats-for-Rent Fund) is aimed at the people who do not have sufficient credit standing and cannot afford to rent flats at market prices. One requirement which has to be met by a tenant is to demonstrate the ability to pay the rent. Accurate prices of rent remain unknown, but they are supposed to be ca. 20 to $30 \%$ cheaper than the market prices and lower than the mean mortgage instalment. Through negotiation of profitable contracts, the prices for utilities will also be cheaper.

The percentage of Poles who rent flats in 2009-2012 was:

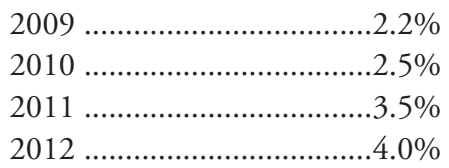


The effect on the market from the governmental programme Mieszkanie dla Młodych will be more complicated. The programme Mieszkanie dla Młodych (MdM, Flats for the Young) is expected to help persons under 35 years of age to purchase a first new flat. The young people who buy (from a developer) or build a new flat will be eligible to apply for the refund. The state support is expected to finance the young persons' own contribution and repay a part of the credit.

According to the Act adopted at the end of September 2012 by the Polish parliament concerning the governmental programme MdM, childless families and single persons will be refunded $10 \%$ of the price of the flat from the state. If a family or a single person has children, the refund will reach $15 \%$. If, within five years from the purchase of the flat, a family has three or more children, they will be eligible to apply for another $5 \%$. The refund is supposed to concern flats with a maximum surface of 50 square metres or houses with a surface of 75 square metres and 100 square metres, respectively. Furthermore, families with three children will be able to purchase a flat or a house in the primary market with the surface bigger by 10 square metres than defined for MdM. The state refund would concern 50 square metres of the flat.

According to the analysts, the launch of the programmes Mieszkanie dla Młodych (January 1, 2014 to December 31,2018) and Fundusz Mieszkań na Wynajem (since 2014) should cause an increase in demand in the market for housing real estate.

Therefore, it can be expected that these programmes, despite their limited scope, will affect not only the increase in demand but also the increase in the prices of flats. Little is known to date about the governmental Fundusz Mieszkań na Wynajem and its scope. However, it can be expected that it will represent an additional factor to reduce the supply of flats.

A vision of the market economy for Europe in the 21st century is contained in Strategy Europe 2020 (COM (2010) 2020). It relates to key challenges for the European community, also facing the era of crises and transformation. It is aimed at supporting transformation of the European Union into a smart and sustainable economy with high employment rates and higher social cohesion. The strategy was presented by the European Commission in March 2010 in Europe 2020: The strategy for smart, sustainable and inclusive growth.

Strategy Europe 2020 represents a continuation of the Lisbon Strategy, which determined the programme of reforms of the European Union over the recent decade. It is based on previous achievements of the partnership for economic growth and creation of workplaces and determines new objectives in order to face new challenges. According to the strategy of Europe 2020, the European Union should focus on the most important areas of its policy, where the cooperation between the Member States is likely to ensure the best outcomes.

The construction sector in the European Union generates some 10\% of the GDP in the EU by employing $7 \%$ of the EU's workforce. European buildings consume as much as $42 \%$ of energy and generate $35 \%$ of greenhouse gases in the entire European Union. Over 50\% of the material extracted from the soil (after processing) is used in the construction sector. Therefore, this sector should be the first to save energy, use renewable sources of energy and limit emission of greenhouse gases.

Sustainable building which focuses on protection of the natural environment and cares for the health and mood of buildings' users has become one of the priority sectors in the European Union. The European Commission included sustainable building into leading sectors (lead market initiative), i.e. the sectors with very high innovation potential and key importance for development of a modern economy in Europe. Both European initiatives and national activities to support sustainable building effect gradual transformation of the paradigm of research problems in construction (Czarnecki, Kaproń, 2010) through extending the criteria of utility of construction products with numerous ecological aspects with respect for a full product life cycle and facilities where they are supposed to be used. 
Today in Poland, few purchasers see the benefits of the application of energy-saving solutions. The most important determinant for the majority of customers is costs rather than environmental protection. Ecological building seems to be not for developers since many purchasers see the benefits of energy-saving solutions. However, despite this fact, developers presented in May 2011 examples of ecological solutions where geothermal installations were used, over-standard insulation, recuperation systems, solar batteries, three-pane windows and Velox walls with improved thermal insulation. According to Michał Kudła, an adviser from Home Broker in Gdańsk (Forsal pl, 2011) despite numerous innovative solutions, prices do not differ much from market prices.

\section{CONCLUSIONS}

An analysis of the situation in the Polish housing market in the post-crisis period showed that:

- in the post-crisis period, a limited supply in the housing market was observed, especially among the most popular types of flats;

- since the beginning of 2010, accessibility of mortgages for purchasing flats is increasing;

- implementation of the Developer's Act resulted in intensification of construction works in the beginning of 2012 and then a slowdown in the number of new building sites in the following periods;

- housing deficits, overcrowding and bad condition of flats affects almost half of the households in Poland;

- improvements in the economy in 2013 generated a strong demand impulse in the real estate market;

- extension of communal resources in Poland is uneconomical, and the system of communal flats should be replaced by a system for supporting the ability of people with the lowest incomes to rent flats in the free market;

- programs for market development in Poland indicate a substantial increase of the surplus of the number of flats by 2020 ;

- governmental projects to support housing needs will strongly affect intensity of development of the housing market;

- the EU's strategy is based on previous achievements of partnership for economic growth, and creation of workplaces and determines new objectives in order to face new challenges; and

- sustainable building, as one of priority sectors in the European Union, is numbered among the leading sectors in the European Union (lead market initiative), i.e. the sectors with very high innovation potential and key importance for development of modern economy in Europe.

\section{REFERENCES}

Bank BGŻ (2014), Stan i perspektywy rozwoju rynku nieruchomości i użytków rolnych w Polsce w 2014 r. // https:// www.google.pl/\#q=Bank+BG\%C5\%BB\%2C+Stan+i+prospektywy+rozwoju+rynku+nieruchomości+i+użytków+r olnych+w+Polsce+w+2014+r+; downloaded on February 16, 2014.

Central Statistical Office (2013), Concise Statistical Yearbook of Poland 2013, Tabl. 10(71), p. 127; Tabl. 8(135), p. 235

$\operatorname{COM}(2010) 2020$, Europe 2020: The strategy for smart, sustainable and inclusive growth, http://europa.eu/legislation summaries/employment_and_social_policy/eu2020/index_en.htm.

Council of Ministers (2011), Główne problemy, cele i kierunki programu wspierania rozwoju budownictwa mieszkaniowego do 2020 roku, Print No. 3725, status: March 4, 2011, adopted by voting and passed to the Commission of the Infrastructure. 
Czarnecki L., Kaproń M. (2010), „Wiadomości Projektanta Budownictwa” Kierunki prac badawczo-rozwojowych w budownictwie, nr 6, s. 30-33

Forsal (2011), Rynek mieszkaniowy w Polsce - prognozy na lata 2012-2022, http://forsal.pl/artykuly/661744,rynekmieszkaniowy-w-polsce-prognozy-na-lata-2012-2022.html, downloaded on April 10, 2012.

Forsal.pl (2011). Ekologia lubiana, ale na rynku nieruchomości niepraktykowana, http://biznes.pl/wiadomosci/kraj/ ekologia-lubiana-ale-na-rynku-nieruchomosci-niepra4358304,news, html downloaded on September 10, 2011.

Gazeta Bankowa (2014), Bezpośrednim celem inicjatywy BGK jest rozruszanie rynku mieszkań na wynajem, a nie obniżenie cen najmu, http://wgospodarce.pl/opinie/7391-bezposrednim-celem-inicjatywy-bgk-jest-rozruszanie-rynkumieszkan-na-wynajem-a-nie-obnizenie-cen-najmu, downloaded on March 1, 2014.

GUS (2010), Zasoby mieszkaniowe w 2010 r., http://www.Koniunktura.com/artykul/open/id/17.

Instytut Analiz - MRN.pl, (2011), Polski Rynek Mieszkaniowy. Analiza Porównawcza Największych Miast, http://www. mrn.pl/analizy/Analizy,3,7.html, downloaded on February 16, 2014.

KNB (2006), Finansowanie nieruchomości przez banki w Polsce, stan na czerwiec 2006, http://www.knf.gov.pl/Images/nieruchomości2006_tcm75-4777.pdf, downloaded on April 10, 2012.

KNB (2007), Finansowanie nieruchomości przez banki w Polsce, stan na czerwiec 2007, http://www.knf.gov.pl/Images/nieruchomości2007_1_tcm75-4776.pdf, downloaded on April 10, 2012.

KNF (2008), Finansowanie nieruchomości przez banki w Polsce, stan na czerwiec 2008, http://www.knf.gov.pl/Images/nieruchomości_06_2008_tcm75-9460.pdf, downloaded on April 10, 2012.

KNF (2010) , Raport o sytuacji banków w 2009 r., http://www.knf.gov.pl/Banki\%202009_raport_tcm_75-22743.pdf, downloaded on April 10, 2012.

Kongres Budownictwa (2009), Sytuacja mieszkaniowa w Polsce na tle doświadczeń europejskich. Stan obecny $i$ zagrożenia. Przygotowano dla Kongresu Budownictwa, Maj 2009, s. 3.

http://www.kongresbudownictwa.pl/pliki/SYTUACJA\%20MIESZKANIOWA\%20W\%20POLSCE.ppt\#256,2,SY TUACJA MIESZKANIOWA W POLSCE NA TLE DOŚWIADCZEŃ EUROPEJSKICH Roman Nowicki Przewodniczący Kongresu Budownictwa, downloaded on February 16, 2014.

Łaszek,J. (2004), NBP, Materiały i Studia, Bariery rozwoju rynku nieruchomości mieszkaniowych w Polsce, Zeszyt nr 184, pp. 32-45.

NBP, Biuro Polityki Makrostabilnościowej (2014) Informacja o cenach mieszkań i sytuacji na rynku nieruchomości mieszkaniowych i komercyjnych w Polsce w IV kwartale 2013r., http://www.nbp.pl/publikacje/rynek_nieruchomosci/ceny_mieszkan_12_2013.pdf, downloaded on April 16, 2014.

PZFD (2012), Sytuacja mieszkaniowa w Polsce 2012, http://www.pzfd.pl/_files/img_sites/Raport\%20Sytuacja\%20 mieszkaniowa\%20w\%20Polsce.pdf downloaded on March 1, 2014.

REAS (2014), Rynek Mieszkaniowy w Polsce - 1 kw. 2014, http://echo.stockwatch.pl/raporty-branzowe/reas-rynekmieszkaniowy-w-polsce-1-kw-2014-r, downloaded on February 6, 2014.

Regiodom (2014), Tanie mieszkanie na wynajem - na czym polega rewolucyjny projekt, http://regiodom.pl/portal/ porady/nieruchomosci/tanie-mieszkania-na-wynajem-na-czym-polega-rewolucyjny-projekt, downloaded on June 20, 2014.

The Act of September 16, 2011 on protection of the rights of purchasers of housing properties and detached houses, Journal of Laws 2011, No. 232 Pos. 1377.

ZBP (2013), Raport AMRON-SARFIN, http://zbp.pl/public/repozytorium/wydarzenia/images/luty_2014/konf/Raport_AMRON-SARFiN_Nr_4_2013_Pl_skrot_fin.pdf, downloaded on March 1, 2014. 